\title{
Editorial Introduction: War Veterans and Fascism
}

\author{
Kristian Mennen \\ Berlin \\ k.m.mennen@gmail.com \\ Wim van Meurs \\ Radboud University, Nijmegen, The Netherlands \\ w.v.meurs@let.ru.nl
}

\begin{abstract}
This special issue of the journal Fascism draws its inspiration from recent developments in the research areas of war studies, cultural history of the First World War, research on political culture and on (international) civil society in historical perspective. It aims to review the approaches and considerations of recent studies about World War veterans and their veterans' organisations for selected European countries in the interwar period. The articles in this themed issue will contribute to an improved insight into the history of fascism and the backgrounds of fascist movements. This introduction will present the general direction of the themed issue and a broad outline of the dominant questions and concerns. It presents recent developments across a broad range of new approaches and perspectives on the history of the interwar period, before outlining the research area of veterans' organisations and the general questions and problems which this themed issue will be considering.
\end{abstract}

\section{Keywords}

Europe-veterans-fascism-FirstWorldWar-commemorationculture-brutalisationcultural demobilization

Although the problem of reintegrating former combatants after the signing of an armistice or peace treaty poses itself for each war and for each post-war 
society, the case of the First World War and its veterans deserves particular attention. ${ }^{1}$ First of all, the Great War as the 'seminal catastrophe of the $20^{\text {th }}$ century'2 exerted a massive influence on the political, social, economic, and cultural history of both belligerent and neutral states. Secondly, the outcome of the First World War and the fate of its veterans are often discerned as major factors in the rise of a new political movement: fascism.

The direct connection between the veterans of the First World War and the rise of fascism was already invoked by the propaganda of Italian Fascism, German National Socialism, and other fascist movements throughout Europe. Mussolini and Hitler appealed to the 'martyrs' of the First World War and to the 'trench experience' as a mystic background and legitimation of their movements' ideological basis.

The historiography of Fascism and National Socialism has traditionally followed the assumption that military defeat in the Great War and the humiliating terms of the armistice and the peace treaties were important factors in the rise of fascism in Germany and Italy. Allegedly the returning war veterans could not adjust to civilian life, developed a deep distrust for traditional political parties, contributed to a profound militarisation of post-war societies, and became trailblazers for right-extremist movements. ${ }^{3}$ However, the cultural history of the First World War itself, the war experience, social composition and political perspectives of war veterans themselves has been relatively neglected in accounts of the rise of fascism. These factors were selectively taken into account as a part of the explanation for the rise of National Socialism, but were in most cases not considered in the context of the larger cultural environment, political culture, and civil society of the time. ${ }^{4}$

1 Stéphane Audoin-Rouzeau and Christophe Prochasson, ed., Sortir de la Grande Guerre : Le monde et l'après-1918 (Paris: Tallandier, 2008); Benjamin Bieber, Wie Kriege enden: Die Reintegration von Soldaten in Nachkriegsgesellschaften (Hamburg: Kovač, 2002); Jörg Duppler and Gerhard Paul Gross, ed. , Kriegsende 1918: Ereignis, Wirkung, Nachwirkung (Munich: Oldenbourg, 1999).

2 George Frost Kennan, The Decline of Bismarck's European Order: Franco-Russian Relations, 1875-189o (Princeton: Princeton University Press, 1979), 3.

3 Jürgen Falter, Hitlers Wähler (Munich: Beck, 1991); Stein Ugelvik Larsen, Bernt Hagtvet and Jan Petter Myklebust, ed., Who Were the Fascists? Social Roots of European Fascism (Bergen: Universitetsförlaget, 1980); Peter Hans Merkl, Political Violence under the Swastika: 581 early Nazis (Princeton: Princeton University Press, 1975); Michael Wildt, Generation des Unbedingten: Das Führungskorps des Reichssicherheitshauptamtes (Hamburg: Hamburger Edition, 2003).

4 Gerd Krumeich, 'Nationalsozialismus und Erster Weltkrieg: Eine Einführung,' in Nationalsozialismus und Erster Weltkrieg, ed. Gerd Krumeich (Essen: Klartext, 2010), 11-20. 


\section{Research Perspectives: Cultural History of War}

New research approaches in the last thirty years have taken the First World War and the experience and perceptions of combatants and civilians as a starting point. These new perspectives contributed to a 'cultural history of war' and introduced aspects of cultural history, gender, 'body politics', and discursive elements into the historiography of the First World War. ${ }^{5}$ Some of these concepts and theoretical perspectives were successfully applied to the interwar period.

Studies on war propaganda and enemy discourses in France and Germany used the concept of a 'culture of war', which was typically characterised by dehumanising images of the war enemy, chiliastic representations of a battle between 'good' and 'evil', and the heroisation of soldiers, patriotism, self-sacrifice and comradeship. ${ }^{6}$ Following on this concept, John Horne pointed to the lack of a 'cultural demobilisation' after 1918. In the aftermath of the First World War, discursive practices did not follow the more or less successful military, political, and economic demobilisation processes. Wartime enemy images and reflexes persisted and included the refusal to accept responsibility for the outbreak of the war or even the mere fact of military defeat. The new international political culture of peace, reconciliation, and conference diplomacy, connected to the new League of Nations in Geneva, was rejected outright or at least severely distrusted. ${ }^{7}$

George Mosse focussed on domestic developments in the interwar period and identified the issue of the 'brutalisation' of postwar society. According to this 'brutalisation thesis', military values, methods, and attitudes of order,

5 Nikolaus Buschmann and Horst Carl, ed., Die Erfahrung des Krieges: Erfahrungsgeschichtliche Perspektiven von der Französischen Revolution bis zum Zweiten Weltkrieg (Paderborn: Schöningh, 2001); Anne Lipp, 'Diskurs und Praxis: Militärgeschichte als Kulturgeschichte,' in Was ist Militärgeschichte? ed. Thomas Kühne and Benjamin Ziemann (Paderborn: Schöningh, 200o), 211-227; Benoît Majerus, 'Kriegserfahrung als Gewalterfahrung: Perspektiven der neuesten internationalen Forschung zum Ersten Weltkrieg,' in Der Bürger als Soldat: Die Militarisierung europäischer Gesellschaften im langen 19. Jahrhundert: ein internationaler Vergleich, ed. Christian Jansen (Essen: Klartext 2004), 271-297.

6 Stéphane Audoin-Rouzeau and Anette Becker, 'Violence et consentement : La "culture de guerre" du premier conflit mondial,' in Pour une histoire culturelle, ed. Jean-Pierre Rioux and Jean-François Sirinelli (Paris: Éditions du Seuil, 1997), 251-271; John Horne, 'Introduction,' 14-18 Aujourd'hui - Today - Heute 5 (2002): 45-53; John Horne, ed., State, Society and Mobilization in Europe during the First World War (Cambridge: Cambridge University Press, 1997).

7 John Horne, 'Locarno et la politique de démobilisation culturelle: 1925-1930', 14-18 Aujourd'hui-Today-Heute 5 (2002): 72-87. 
discipline, and command lines returned home with the demobilised war veterans and disrupted the civil standards of peacetime society and the will to adhere to democratic procedures and find political compromises. Because society had become used to a certain level of physical and verbal violence, it could consider political violence in the streets and venomous propaganda as 'normal. ${ }^{8}$ For part of British, French, and Italian soldiers, the experience of protracted war and violence in a colonial context after 1918 might also account for their turn towards authoritarian or fascist ideological principles. ${ }^{9}$ Robert Gerwarth convincingly argued that the genocidal logic of the excessively violent conflicts in Eastern and East Central Europe after 1918 serves as a more plausible explanation of 'brutalisation' than the First World War itself, and were a prelude to the continuing tensions in this region through the twentieth century. ${ }^{10}$ In many European countries, military leaders aspired to political prominence: Alexandru Averescu (briefly) became Prime Minister of Romania; Józef Piłsudski and Philippe Pétain both became state president when the political order in their respective countries was in danger. They were supposed to safeguard the state from the onslaught of extremist movements, but by doing so paved the way for more 'disciplined' and authoritarian forms of government. ${ }^{11}$

8 George Lachmann Mosse, Fallen Soldiers: Reshaping the Memory of the Two World Wars (Oxford: Oxford University Press, 1990), 159-181; Jon Lawrence, 'Forging a Peaceable Kingdom: War, Violence, and Fear of Brutalization in Post-First World War Britain, The Journal of Modern History 75 (2003): 557-589; Antoine Prost, 'Brutalisation des sociétés et brutalisation des combattants,' in Les sociétés en guerre 1911-1946, ed. Bruno Cabanes and Édouard Husson (Paris: Armand Colin, 2003), 99-111; Dirk Schumann, 'Europa, der Erste Weltkrieg und die Nachkriegszeit: Eine Kontinuität der Gewalt?' Journal of Modern European History 1 (2003): 24-43.

9 Caroline Campbell, 'The Colonial Roots of Political Violence in France: The Croix de Feu, the Popular Front and the Riots of 22 March 1936 in Morocco,' in Political Violence and Democracy in Western Europe, 1918-1940, ed. Chris Millington and Kevin Passmore (Basingstoke: Palgrave Macmillan, 2015), 127-143; Hans-Ulrich Wehler, 'Transnationale Geschichte - Der neue Königsweg historischer Forschung?' in Transnationale Geschichte: Themen, Tendenzen und Theorien, ed. Gunilla Budde, Sebastian Conrad and Oliver Janz (Göttingen: Vandenhoeck \& Ruprecht, 2006), 161-174.

10 Robert Gerwarth, The Vanquished: Why the First World War Failed to End, 1917-1923 (London: Allen Lane, 2016).

11 Giovanni Capoccia, Defending Democracy: Reactions to Extremism in Interwar Europe (Baltimore/London: Johns Hopkins University Press, 2007); Peter Fritzsche, 'Presidential Victory and Popular Festivity in Weimar Germany: Hindenburg's 1925 Election,' Central European History 23 (1990): 205-224; Chris Millington, From Victory to Vichy: Veterans in Interwar France (Manchester: Manchester University Press, 2012). 
Last but not least, John Horne introduced the concept of 'the culture of victory' for the former Entente powers, to complement Wolfgang Schivelbusch's term 'culture of defeat', which would particularly apply to interwar Germany. ${ }^{12}$ Because France, Great Britain, and other Allied and associated states, on one hand, had won the war, veterans could count on a certain level of appreciation and admiration in their home societies. The public discourse about war and the central function of war commemoration ceremonies conferred an honourable meaning to the experience, suffering and death of soldiers in the trenches. German society, on the other hand, had to cope with the memory of wartime defeat and with the blame of starting the war. The German 'culture of defeat' and German endeavours to revise the Versailles peace treaty dominated both foreign and domestic policy during the Weimar Republic. ${ }^{13}$ Italy formally belonged to the victor powers. However, the fact that the country remained neutral until 1915 and the traumatic defeat at Caporetto in 1917, which dominated the Italian war experience, contributed to the emergence of a 'culture of defeat' directly after the war. The war veterans, especially the former arditi, and the minimal spoils of the war effort were instrumentalised for domestic political purposes and for a foreign policy which aimed at revising the so-called 'vittoria mutilata' after the Paris peace treaties. ${ }^{14}$

The macro perspective of culture, society, and discursive narratives of war and peace is complemented by a focus on the social and economic aspects of the demobilisation process. One of the crucial questions concerning the roots and origins of fascist movements, the successful reintegration of war veterans in the labour market and in prewar social and economic structures, can hardly be answered unequivocally. This heavily depended on the age cohort, family situation, and the regional and religious background of the combatants. ${ }^{15}$

12 John Horne, 'Defending Victory: Paramilitary Politics in France, 1918-1926: A CounterExample,' in War in Peace: Paramilitary Violence in Europe after the Great War, ed. Robert Gerwarth and John Horne (Oxford: Oxford University Press, 2012), 216-233; Wolfgang Schivelbusch, Die Kultur der Niederlage: Der amerikanische Süden 1865, Frankreich 1871, Deutschland 1918 (Frankfurt: Fischer Taschenbuch Verlag, 2007).

13 Boris Barth, Dolchstoßlegenden und politische Desintegration: Das Trauma der deutschen Niederlage im Ersten Weltkrieg 1914-1933 (Düsseldorf: Droste, 2003).

14 Patrizia Dogliani, 'Sortir de la Grande Guerre, entrer dans le fascisme: le cas italien', in Sortir de la Grande Guerre, 113-138; Mark Jones, 'From Caporetto to Garibaldiland: Interventionist War Culture as a Culture of Defeat,' European Review of History 15 (2008): 659-674; Marco Mondini, 'La festa mancata: I militari e la memora della Grande Guerra, 1918-1923', Contemporanea 7 (2004): 555-578.

15 Dominique Fouchard, Le poids de la guerre : Les poilus et leur famille après 1918 (Rennes: Presses universitaires de Rennes, 2013); Adam R. Seipp, The Ordeal of Peace:Demobilization 
The 'brutalisation thesis' suggests that the reintegration of war veterans failed after 1918, and that their wartime habits dominated postwar society. Their political activity and their influence on political culture in the interwar period prepared or at least facilitated the rise of fascist mass movements, according to this thesis.

\section{Research Perspective: Veterans' Organisations}

In order to determine and analyse the political and civil society activity of war veterans, veterans' organisations as key collective actors have received more attention in recent years. They were the subject of the workshop 'Veteran Internationalism and the Cultures of Victory and Peace (1919-1933)', in Dublin in October $2009,{ }^{16}$ and of the conference 'Veterans or Socialists? Socialism and Militarism in the Nationalist and Protofascist Movements and Regimes (1918-1945)' in Trento in May 2012. ${ }^{17}$ These conferences and the publications that they yielded have given rise to four main conclusions regarding the connection between war veterans, political culture in the interwar period and the rise of fascism.

First of all, veterans' organisations were not necessarily politically orientated or paramilitary leagues. They were, rather, normal civil society organisations, pursuing the political and economic representation of veterans, war invalids, or war widows and orphans, organising social and cultural events, or taking up functions in youth welfare or national education. The return of millions of veterans to a civil existence, to their prewar jobs and to their families, placed unprecedented challenges and financial burdens on the combatant states. Apart from the war debts and the massive costs of reconstruction of devastated regions, state authorities were obliged to pay pensions to disabled veterans and to widows and war orphans. ${ }^{18}$ The concept of 'civil society' will

and the Urban Experience in Britain and Germany, 1917-1921 (Farnham: Ashgate, 2009); Benjamin Ziemann, Front und Heimat: Ländliche Kriegserfahrungen im südlichen Bayern 1914-1923 (Essen: Klartext, 1997).

16 Published as: Julia Eichenberg and John Paul Newman ed., The Great War and Veterans' Internationalism (Basingstoke: Palgrave Macmillan, 2013).

17 Alessandro Salvador and Anders G. Kjøstvedt, ed., New Political Ideas in the Aftermath of the Great War (Basingstoke: Palgrave Macmillan, 2016).

18 Audoin-Rouzeau and Prochasson, ed., Sortir de la Grande Guerre; Richard Bessel, Germany after the First World War (Oxford: Clarendon Press, 1993); Bruno Cabanes, La victoire endeuillée: La sortie de guerre des soldats français, 1918-1920 (Paris: Éditions du Seuil, 2004); Deborah Cohen, The War Come Home: Disabled Veterans in Britain and Germany, 1914-1939 
in this context need to be considered in a historical context. A modern-day definition which presupposes high standards for 'civil society' and excludes everything 'military' in background and style, does not quite fit to the political and cultural conditions of the interwar period. ${ }^{19}$

A second aspect of this civil society engagement of veterans' organisations consists of their active involvement in war commemorations. The First World War played an immense role in the commemorative culture of next to all European countries after 1918. The 'cult of the fallen' and the establishment of national monuments, most notably the tombs of Unknown Soldiers, centred on the war veterans as the living representatives of the generation which fought and died for their country, and which deserved the fatherland's eternal gratitude. ${ }^{20}$ The elevation of war commemoration ceremonies to a factor of national unity was, however, not everywhere as successful. In Germany, the protracted debates about the interpretation and meaning of war, wartime experience, and defeat precluded a unitary discourse about the First World War and severely hampered the legitimacy of the German Republic. ${ }^{21}$

The nature and development of international reconciliation can be discerned as a third result of recent interest in veterans' organisations. French, British, and German veterans' leagues found a common understanding about the shared suffering in the trenches of the Great War and agreed upon joint commemoration ceremonies. The war experience and the firm conviction never to wage war again formed the backbone of a profoundly felt pacifism in many veterans' organisations. They did purposively meet their former

(Berkeley: University of California Press, 2001); Martina Salvante, 'Italian Disabled Veterans between Representation and Experience,' in Men After War, ed. Stephen McVeigh and Nicola Cooper (New York: Routledge, 2013), 111-129.

19 Jürgen Kocka, 'Civil Society in Historical Perspective,' in Civil Society: Berlin Perspectives, ed. John Keane (New York/Oxford: Berghahn Books, 2006), 37-50; Frank Trentmann, 'Introduction,' in Paradoxes of Civil Society: New Perspectives on Modern German and British History, ed. Frank Trentmann (New York: Berghahn Books, 200o), 3-46.

20 Bruno Cabanes, 'Les vivants et les morts : La France au sortir de la Grande Guerre,' in Sortir de la Grande Guerre, 27-45; Ken Inglis, 'Entombing Unknown Soldiers : From London and Paris to Baghdad,' History and Memory 5, no. 2 (1993): 7-31; Oliver Janz, Das symbolische Kapital der Trauer: Nation, Religion und Familie im italienischen Gefallenenkult des Ersten Weltkriegs (Tübingen: Niemeyer, 2009).

21 Nicolas Beaupré, Das Trauma des großen Krieges 1918-1932/33 (Darmstadt: WBG, 2009); Sabine Behrenbeck, 'Zwischen Trauer und Heroisierung: Vom Umgang mit Kriegstod und Niederlage nach 1918,' in Kriegsende 1918: Ereignis, Wirkung, Nachwirkung, ed. Jörg Duppler and Gerhard Paul Gross (Munich: Oldenbourg, 1999), 315-339; Benjamin Ziemann, Contested Commemoration: Republican War Veterans and Weimar Political Culture (Cambridge: Cambridge University Press, 2013). 
adversaries on the former battlefields and on the war cemeteries of Flanders and Northern France and actively involved the youth in exchange and reconciliation programmes. Initiatives like the German Kriegsgräberfürsorge [care of war graves] and student exchanges were based on such sentiments. ${ }^{22}$ For sure, these reconciliation measures and initiatives were not confined to left-wing, socialist-internationalist, or genuinely pacifist veterans' organisations. Mussolini used the international network of veterans' organisations for the interests of Italian foreign policy, and the Nazi regime and its Nationalsozialistische Kriegsopferversorgung [NSKov; National Socialist War Victim's Care] institution actively maintained close contacts with right-wing and conservative veterans' organisations in France and Britain as late as 1938. ${ }^{23}$

Fourth, the international and pacifist view of veterans' organisations was expressed in their commitment to civil society of the interwar period. The veterans' organisations from the former Entente countries soon formed an international federation, called the Fédération Interalliée des Anciens Combattants (FIDAC). Ongoing normalisation and reconciliation efforts resulted in the founding of the so-called Conférence Internationale des Associations de Mutilés et Anciens Combattants (CIAMAC) in 1925: this international federation of veterans' organisations did include representatives from the former Central Powers. Both international federations spoke up for peace, disarmament, a system of international arbitration, and a general climate of international understanding. Their influence on the League of Nations, the International Labour Organisation, and other international organisations of that time found its summit in coordinated FIDAC and CIAMAC actions at the Geneva disarmament conference in $193^{2-1934}{ }^{24}$

22 Susanne Brandt, Vom Kriegsschauplatz zum Gedächtnisraum: Die Westfront 1914-1940 (Baden-Baden: Nomos, 200o); Christian Weiß, “Soldaten des Friedens": Die pazifistischen Veteranen und Kriegsopfer des Reichsbundes und ihre Kontakte zu den französischen anciens combattants 1919-1933,' in Politische Kulturgeschichte der Zwischenkriegszeit 1918-1939, ed. Wolfgang Hardtwig (Göttingen: Vandenhoeck \& Ruprecht, 2005) 183-204, here: 192-201.

23 Martina Salvante, 'The Italian Associazione Nazionele Mutilati e Invalidi di Guerra and its International Liaisons in the Post Great War Era,' in The Great War and Veterans' Internationalism, ed. Julia Eichenberg and John Paul Newman (Basingstoke: Palgrave Macmillan, 2013), 162-183; Holger Skor, Brücken über den Rhein: Frankreich in der Wahrnehmung und Propaganda des Dritten Reiches, 1933-1939 (Essen: Klartext, 2011), 203-277; Claire Moreau Trichet, Henri Pichot et l'Allemagne de 1930 à 1945 (Bern: Peter Lang, 2004).

24 Thomas Richard Davies, The Possibilities of Transnational Activism: The Campaign for Disarmament between the Two World Wars (Leiden: Brill, 2007); Antoine Prost and Jay Winter, René Cassin and Human Rights: From the Great War to the Universal Declaration (Cambridge: Cambridge University Press, 2013). 
The cultural and discursive aspects of fascism and fascist ideological views have been historiographically en vogue in recent years. ${ }^{25}$ However, the subsequent emphasis on war commemoration, the cult of the First World War, its soldiers, and 'front experience' did not always take into account the perspective of the actual war veterans and their organisations. As a result of this, the historiography of fascism seems to reproduce fascist propaganda claims that the fascist movements represented 'the front soldiers', without the appropriate empirical background to assess the links between war veterans and fascism.

When veterans' organisations directly influenced politics, they could either recommend voting for a fascist party or have veterans' representatives themselves run for parliament or for a political office on behalf of the party or movement. An indirect factor is the shared responsibility of veterans for the creation of a political culture in which fascist movements could prosper and flourish later. If veterans' organisations directly or indirectly were part of tendencies towards a 'brutalised' or 'militarised' style and rhetoric of politics, or a 'culture of defeat', and thereby contributed to the rise of fascism, this contrasts sharply to their activities as internationally orientated and pacifistic civil society actors. Veteran initiatives for international reconciliation, joint commemorations and the efforts towards a lasting peace in Europe would at first sight counter fascist movements and their demands in the field of foreign policy.

\section{Scope and Content of this Special Issue}

The objective of this special issue is to provide a better understanding of the contradictory roles played by veterans' organisations. The comparative approach allows to debunk generalising statements about veterans as main supporters and advocates of fascist parties and movements by drawing on counter-examples and by elaborating on the large cultural and discursive diversity of veterans' organisations, even within one country and one cultural context. Some veterans' associations supported a newly established authoritarian dictatorship, others invigorated the democratic system, while aggravating political tensions despite best intentions, or adopted a combination of these action repertoires. Each contribution will summarise the findings and insights from the most recent historiography in each country for the history

25 Constantin Iordachi, ed., Comparative Fascist Studies: New Perspectives (London: Routledge, 2010); Sven Reichardt, 'Neue Wege der vergleichenden Faschismusforschung,' Mittelweg 36 (2007): 9-25; Thomas Schlemmer and Hans Woller, ed., Der Faschismus in Europa: Wege der Forschung (Munich: Oldenbourg, 2014). 
of veterans and their direct and indirect involvement in the "brutalisation of politics' and the rise of fascism.

Similarly, several factors identified in the contributions draw the attention to productive new approaches and directions of research, which are not yet fully covered in national and internationally comparative studies. This applies in particular to the question of war memory and war commemoration as well as to generational aspects in the rise of fascist movements. For the understanding of political violence after 1918, the contributions in this issue point to the experience of the First World War, the imagination of war experience and postwar traumatic violent conflicts, as possible factors.

In the first contribution to this special issue, Kristian Mennen addresses Germany, where National Socialism managed to mobilise a mass movement and engender support from civil society. Based on an overview of recent research, Kristian Mennen's case study on veterans' organisations in the Weimar Republic demonstrates their contrary understandings of collective war memory and their different definitions of 'veteran' and 'front experience'. The evidence suggests that we should dismiss traditional views, according to which disappointed and politically radicalised war veterans formed the backbone of the Nazi membership. Mennen argues that the heroic and idealistic discourse of war which gained dominance in Weimar political culture, was produced by members of the 'war youth generation', who were actually too young to have fought in the war themselves.

John Paul Newman examines the political and ideological position of war veterans in the interwar Kingdom of Yugoslavia. The category of 'war veterans' is explicitly extended to members of the Chetnik irregular militias who fought for the 'liberation' of the 'southern territories' from 1912 onwards. Whereas official ideology in the new multi-ethnic state was closely aligned to the Entente 'culture of victory', in accordance with the dominant narrative of the Serbian war effort, many Yugoslav war veterans had fought in the armies of the Central Powers. ${ }^{26}$ Newman argues that, although fascism was not a major part of the war veteran question in interwar Yugoslavia, war veterans and their 'parafascist' associations were central to the identity and membership of the country's fascist groups. This is demonstrated by a careful description of political discourse and 'brutalisation' in Yugoslavia and an analysis of the most relevant veterans' organisations.

Constantin Iordachi and Blasco Sciarrino add another significant case study with their article about the relationship between patterns of demobilisation,

26 John Paul Newman, Yugoslavia in the Shadow of War: Veterans and the Limits of State Building, 1903-1945 (Cambridge: Cambridge University Press, 2015). 
fascism, and veterans' activism in Romania. Romania belonged to the victorious Entente powers and saw its wildest territorial ambitions miraculously fulfilled in 1918. The authors compare the process of war mobilisation and demobilisation in Romania in the years 1916-1920 to European-wide developments. Their contribution analyses the successful demobilisation and national legislation in favour of ex-servicemen in interwar Romania. In a comparison between veterans and the emergence of fascism in Italy and Romania, the authors provide important suggestions concerning this connection in different national circumstances. 